\title{
Factors influencing water allocation and entitlement prices in the Greater Goulburn area of Australia
}

\author{
S. Wheeler ${ }^{1}$, H. Bjornlund ${ }^{1,2}$, M. Shanahan ${ }^{1}$ \& A. Zuo ${ }^{1}$ \\ ${ }^{1}$ CRMA, University of South Australia, Australia \\ ${ }^{2}$ Economics Department, University of Lethbridge, Alberta, Canada
}

\begin{abstract}
This paper examines the factors that influence the price of water allocations and entitlements by using actual monthly prices paid for water allocations and entitlements from 1993 to 2007. Water allocation prices are influenced by seasonal factors, current water allocations received, some rural commodity prices and policy impacts. The price of water entitlements are most significantly influenced by current prices of water allocations, allocations currently received, seasonal factors and government water policy. Such an analysis highlights the importance of government policy in influencing water markets.
\end{abstract}

Keywords: water markets, allocation water prices, entitlement water prices.

\section{Introduction}

Australia has increasingly promoted markets in water allocations and entitlements as an integral part of agricultural water management. Water markets have been functioning in Australia since 1984 and by now farmers in all states can buy and sell water on a temporary basis (allocation trading), or on a permanent basis (entitlement trading), as required. Farmers may sell their 'allocation' each year (the amount the government announces each may receive each year, based on rainfall and water storage conditions) or their 'entitlement' (the amount of water that 'by right' is linked to their ownership of property and is permanently associated with that land (unless sold).

Within the Goulburn-Murray Irrigation District (GMID) in Victoria market prices for both entitlements and allocations have increased considerably since 
1993 with a mean annual growth of allocation prices of $20.2 \%$ and $12.3 \%$ for entitlement prices. There is also clear evidence that the two prices are closely linked, following the same cyclical pattern but with allocation prices fluctuating more than twice as much as entitlement prices [1,2].

Comprehension of the various factors underlying price determination in water markets is essential in order to understand the effects of climate, policy changes and other shifts in market factors. Prices are determined by the interaction between supply and demand of water, which are in turn influenced by a range of other policy and market factors. Generally, economic analysis of agricultural prices considers factors such as stocks, imports, production, usage and exports. However, modeling water prices is slightly different and despite agricultural water markets being in existence for some twenty years in Australia, there have only been a few attempts to estimate the factors impacting on prices paid for water in the markets for water allocations and entitlements; mainly because of the difficulty in obtaining data and relatively thin trading in these markets.

The GMID is Australia's largest irrigation district, and is the area upon which this study is based (Figure 1). The GMID is located in Northern Victoria along the River Murray which itself forms the border with New South Wales. Irrigation within the district is mainly supplied by two major sources: the Goulburn and the Murray Rivers.

Initially, trade in this region in both the markets for water allocations and entitlements were low. Trading by irrigators has increased considerably in the area, and by July 2004, more than eighty per cent of farm businesses within the GMID had traded some type of water at some time. During very dry seasons, the percent of farm businesses active in buying or selling allocations or entitlements increases considerably with more than $60 \%$ of farm businesses trading during the season of 2002/03 [3].

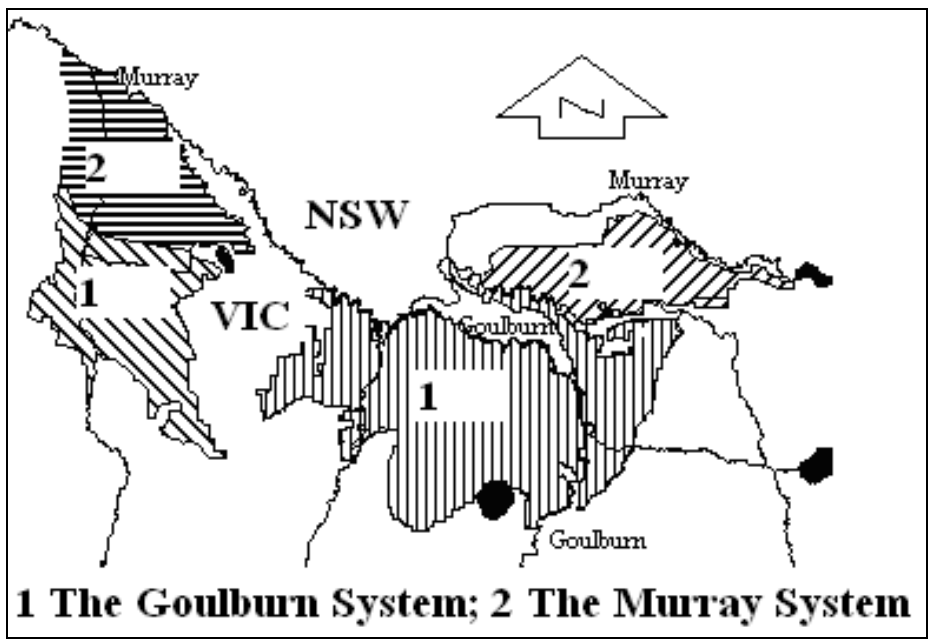

Figure 1: The Goulburn-Murray Irrigation District. 


\section{Influences on prices - overview and literature review}

Figure 2 displays the allocation and entitlement water prices paid in the GMID from 1993 to 2007.

Although allocation and entitlement prices have increased steadily since water trading began, they have been very variable, and seem to be strongly influenced by seasonal conditions such as the drought in 2002-03 and 2006-07.

Most economic work in water markets has concentrated on modeling water demand rather than water prices (i.e. Scheierling et al. [4] present a metaanalysis of 24 studies on allocation water demand in the United States). Wheeler et al. [2] analyzed demand for water allocations while Wheeler et al. [5] analyzed demand for water entitlements in the GMID.

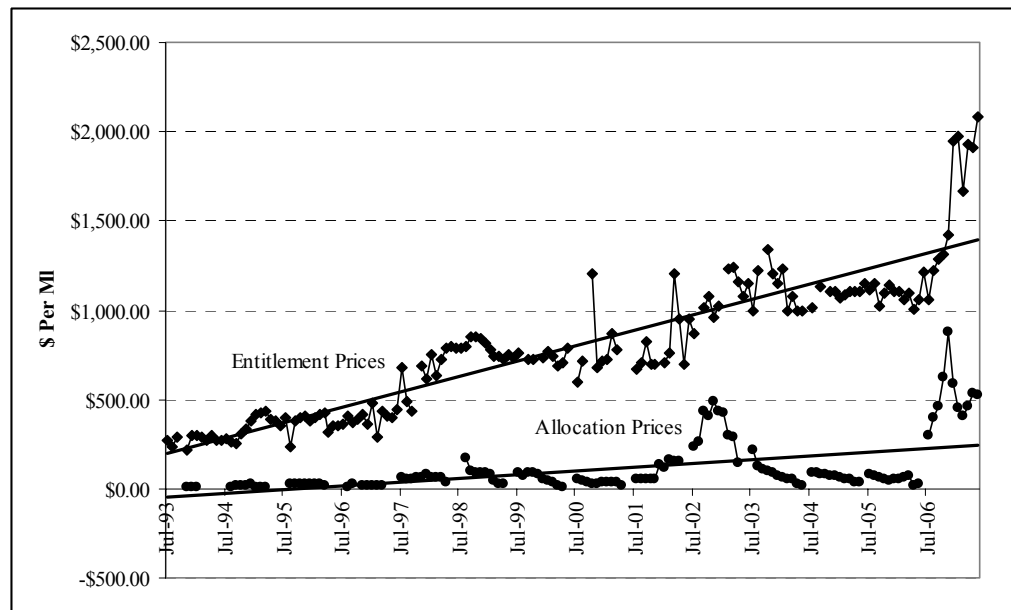

Figure 2: $\quad$ Monthly average prices paid for water allocations and entitlements in the Greater Goulburn from 1993 to 2007.

There are few studies of the factors influencing water market prices. Two exist for the US; one analyzes individual water transactions [6] and one analyzes mean annual prices [7]. It was found that the factors that most influence entitlement prices in the United States were urban and industrial activity in the market, the priority of the water right that is traded, the volume of water traded, and prior to urban expansions in Colorado, agricultural commodity prices. Two studies exist for Australia. These found that the major influences identified in the US studies - priority of water rights and competition from urban and industrial users, are not relevant for Australia. A recent analysis by Bjornlund and Rossini [8] analysing average monthly entitlement prices in the GMID from 1993 to 2003 found that entitlement prices were most influenced by water scarcity, price of water allocations, interest rates and some commodity prices. An earlier study analysing individual transactions of water entitlements found that the major determinants of entitlement prices are the level of restrictions on trade in the 
area, the water use efficiency of buyers and sellers, the value of commodities produced and the relative bargaining strength of the buyer and seller [9].

The single study on factors influencing the market price of water allocations of which we are aware is by Bjornlund and Rossini [10]. They studied water allocation prices in the GMID from 1993 to 2003 and found prices were most influenced by water scarcity, rainfall and evaporation. The present study builds on the earlier analyses by Bjornlund and Rossini $[8,10]$ and provides a more structurally rigorous model and longer dataset over a period of severe drought in the GMID.

\section{Methodology and results}

\subsection{Influences on average monthly allocation and entitlement prices}

Price demand functions have traditionally used linear, log-log or log-linear functional forms, with the most popular being the log-log functional form (i.e. [11]). This section calculates influences on prices of allocation and entitlement water for the period of 1993 to 2007 utilizing average monthly prices paid for water allocations and entitlements. The specifications for the models for average entitlement prices (AEPrice) and average allocation prices (AAPrice) respectively are:

$\ln _{\text {AEPrice }}=\beta_{0}+\beta_{1}$ lnAAPrice $_{\mathrm{t}}+\beta_{2}$ lnMAlloc $_{\mathrm{t}}+\beta_{3}$ Drought $_{\mathrm{t}}+\beta_{4}$ NDKyab $_{\mathrm{t}}+$ $\beta_{5}$ CommodityPrices $_{\mathrm{t}}+\beta_{6} \operatorname{lnFarmGDP}_{\mathrm{t}}+\beta_{7}$ Month $_{\mathrm{t}}+\beta_{8}$ Year $_{\mathrm{t}}+\beta_{9}$ Policy $_{\mathrm{t}}$

$\ln$ AAPrice $_{\mathrm{t}}=\beta_{0}+\beta_{1}$ lnMAlloc $_{\mathrm{t}}+\beta_{2}$ Drought $_{\mathrm{t}}+\beta_{3}$ NDKyab $_{\mathrm{t}}+\beta_{4}$ CommodityPrices $_{\mathrm{t}}$ $+\beta_{5} \operatorname{lnFarmGDP}_{\mathrm{t}}+\beta_{6}$ Month $_{\mathrm{t}}+\beta_{7}$ Year $_{\mathrm{t}}+\beta_{8}$ Policy $_{\mathrm{t}}$

where $\mathrm{t}$ is the time period, and the monthly average prices paid/received for water entitlements and allocations by farmers in the GMID are the dependent variables. Water allocation prices are used as an independent variable in the entitlement price model, as it is expected that they should have a positive influence on entitlement prices (as when water allocation prices go up, then it becomes more rational to invest in water entitlements). Bjornlund and Rossini $[1,8]$ found such an effect.

The next independent variable MAlloc $_{t}$ is the current allocation level of irrigation water for that month, and it is expected to have a negative influence on both types of prices, as when farmers receive higher allocations it decreases their need/incentive to buy more water, hence decreasing the willingness to pay for additional water. It is expected that the allocation level should have a greater influence on allocation prices than entitlement prices. Drought is a dummy for the two severe drought years of 2002-03 and 2006-07, and it is hypothesised

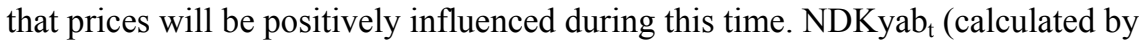
subtracting monthly rainfall from monthly evaporation rates obtained form the Bureau of Meteorology for the Kyabram station) is the net monthly water deficit in the region. It is expected that an increase in the net water deficit (that is, more 
water is evaporating from the soil than is being replaced by rainfall), will lead to an increased demand (and hence price) for water, as suggested by some results in Brennan [12] and Bjornlund and Rossini [9]. Again, theory would suggest that the relationship between $\mathrm{NDKyab}_{\mathrm{t}}$ and allocation prices should be stronger than the relationship with entitlement prices.

The fourth independent variable in the allocation price model is commodity prices, namely using the price of feed barley (PriceFB ${ }_{t}$ ) and the price of red wine: the fifth independent variable in the entitlement price model. (Note too that a wide variety of agricultural prices were collected and tested but no others displayed any significance in the models suggesting that during this period of high scarcity levels the main driver of price is scarcity rather than commodity prices. Farmers are buying to minimize their losses rather than maximizing their profits. They buy water to protect their investment in diary herd and equipment or permanent plantings).

Prices for barley and wine are the unit export commodity prices received (provided by the Australian Bureau of Agricultural Resource Economics). Previous studies have found some relationship between water prices and commodity prices $[8,10]$. One of the largest buyers of water allocations over this time period has been dairy farmers, who can choose to water their grass or buy feed barley to feed their cows. Hence, feed barley can be a substitute for buying water, suggesting a positive relationship between water allocations and feed barley, though there is no expected relationship between water entitlements and feed barley. Another significant influence on prices may have been the price of red wine (the price of red wine has been significantly higher than the price of white wine over the time period in question). Permanent plantings of viticulture over the course of the past decade have significantly increased the demand for water downstream. It is expected that this would have more of an effect on water entitlements than water allocations, because farmers would need an ongoing water source for their vines. Commodity prices, apart from wine grapes, are not expected to have an influence on entitlement water prices.

FarmGDP $_{t}$ is the average monthly farm GDP as estimated by the Reserve Bank of Australia (RBA). It is hypothesised that farm GDP (which is a proxy for income of farmers) will be positively related to water prices.

Month is a seasonal dummy for the three months of highest trading in the year (January, February and March - high summer). It is expected that there will be a positive influence on prices in this period, though the relationship is theorized to be stronger with allocation prices than entitlement prices. Year is a continuous variable for the trading year in the database to detect if there is a time trend or some effect associated with a developing regional water market over time. The last independent variable is Policy ${ }_{t}$, which is a dummy variable for 1998, reflecting two main water policy changes. First, this was the year that the Northern Victoria Water Exchange was introduced, providing fast, cheap and secure trading in water. Second, from 1998 onwards the water authority changed its allocation policy, and only incorporated minimum expectations to inflows during the seasons (resulting in lower opening allocations) [3]. Such policy changes are expected to have a positive influence on water demand and prices. 
Table 1: Monthly allocation and entitlement actual prices in the GMID 1993 to 2007.

\begin{tabular}{|l|c|c|c|l|c|c|c|}
\hline \multicolumn{5}{|c|}{ Allocation Prices } & \multicolumn{5}{c|}{ Entitlement Prices } \\
\hline & Coef. & $t$ & $P>|t|$ & & Coef. & $t$ & $P>|t|$ \\
\hline lnalloc & -0.24 & -2.02 & 0.05 & lnaaprice & 0.09 & 2.39 & 0.02 \\
\hline drought & 0.43 & 1.20 & 0.23 & lnalloc & 0.02 & 0.32 & 0.75 \\
\hline ndkyab & 0.00 & 1.02 & 0.31 & drought & -0.02 & -0.20 & 0.85 \\
\hline lnpricefb & 0.64 & 1.60 & 0.11 & ndkyab & 0.00 & -0.74 & 0.46 \\
\hline Inpricerw & 0.31 & 0.65 & 0.52 & lnpricerw & 0.29 & 1.62 & 0.11 \\
\hline Infarmgdp & -0.57 & -1.01 & 0.31 & lnfarmgdp & 0.01 & 0.04 & 0.97 \\
\hline month & 0.04 & 0.48 & 0.63 & month & 0.06 & 1.93 & 0.06 \\
\hline yeartrend & 0.16 & 4.11 & 0.00 & yeartrend & 0.09 & 7.91 & 0.00 \\
\hline policy & 1.13 & 1.86 & 0.07 & policy & 0.29 & 2.25 & 0.03 \\
\hline cons & 4.46 & 0.84 & 0.41 & cons & 4.86 & 2.79 & 0.01 \\
\hline $\mathrm{n}$ & 128 & & & $\mathrm{n}$ & 115 & & \\
\hline Adj $\mathrm{R}^{2}$ & 0.74 & & & Adj R & 0.99 & & \\
\hline F Test & 40.21 & & & F Test & 868.56 & & \\
\hline Prob $>\mathrm{F}$ & 0.00 & & & Prob $>\mathrm{F}$ & 0.00 & & \\
\hline $\begin{array}{l}\text { DurbinWa } \\
\text { tson Stat }\end{array}$ & 1.60 & & & $\begin{array}{l}\text { DurbinWa } \\
\text { tson Stat }\end{array}$ & 1.97 & & \\
\hline
\end{tabular}

Water volume was not used in either price model specification because of the problem of endogeneity. Lagged allocation and entitlement prices could also not be used in either model because of collinearity problems. Real prices (base year of 1996-97) were used in all models.

Table A1 in Appendix 1 provides a summary of the descriptive statistics (in terms of means, minimums, maximums and standard deviations) for the average price monthly model from July 1993 to June 2007.

Table 1 presents the results of the two models (the allocation price model has 128 monthly observations and the entitlement price model has 115). These final specifications showed no problems with heteroscedasticity or multicollinearity, however they did have a problem with serial correlation. We addressed this problem by using Prais-Winsten AR(1) regressions (iterated estimates) for both models.

The analysis shows that the price of water allocations are significantly and positively influenced by a year trend and government policy introduced in 1998 (the price of feed barley was very weakly significant at 11 per cent). The price of water allocations in the current month was negatively and significantly related to the current allocation level. In further testing of the model, we tested for significance of lags of key variables. When lagged by one month, allocation levels are still significant and net deficit of water also becomes significant with both having the correct sign as hypothesized. This suggests that farmers may be reacting to weather in the previous month in the market for water allocations, 
although the current weather does not seem to influence significantly allocation prices.

The price of water entitlements is significantly and positively influenced by allocation prices, the month, a year trend, and policy introduced in 1998 (the price of red wine was also very weakly significant at 11 per cent.

Overall, more variation in entitlement prices was explained than the variation in allocation prices. The most significant influence on entitlement prices was the year trend, highlighting the fact that over time investing in water entitlements has proved much more profitable for irrigators. The other most significant influence on entitlement prices was allocation prices, which are correlated to a degree because they have both increased in value over the time period in question (but not to the extent to cause problems with collinearity in the model). As allocations become more expensive, it is only rational that irrigators are willing to pay higher prices for water entitlements in order to reduce the need to buy allocations and to ensure a more secure supply during periods of scarcity.

The price of water allocations over the time period from 1993 to 2007 has been much more influenced by short-term factors (such as the drought, the current allocation of water received and the net deficit of water) than the prices of water entitlements - with the exception of the seasonal month influence - the dummy for January, February and March. Permanent plantings of grapes, and hence the prices received, seemed to have had an influence on the prices of entitlement water in the GMID, but not so much water allocations. The key change in water policy in 1998 had a significant and large positive influence on both allocation and entitlement prices, indicating that government policy can make a significant difference to water prices through administrative changes. Time itself has been the most significant factor in influencing entitlement prices. Over time the demand and prices paid for water entitlements has increased significantly as irrigators recognise the need to have long-term secure rights to a resource that is proving to be more and more finite.

There are a number of key differences between the results of this paper and Bjornlund and Rossini [8, 10]. Such differences arise because of the different functional and theoretical form of the model/s, differences in the data of key variables (such as commodity prices), and a longer time-series of data used.

\section{Conclusion and policy recommendations}

This paper has provided an estimate of the factors influencing the prices of water entitlements and water allocations within one region along the Murray River in Australia over the period 1993 to 2007. It was found that there were key differences between the models for water allocations and water entitlements. Water allocations are much more influenced by short-term water factors (such as drought and allocation received), while the price of water entitlements is much more likely to be influenced by variables such as a time trend and the price of water allocations. Water policy changes in 1998 significantly influenced the prices paid in both markets for water allocations and water entitlements, indicating that governments can indeed play a role in regulating the market with administrative changes. 


\section{Acknowledgements}

This research is part of a larger project funded by the Australian Research Council and six industry partners: Murray-Darling Basin Commission, Department of Natural Resources; Department of Sustainability and Environment, Goulburn-Murray Water, Department of Water, Land and Biodiversity Conservation and UpMarket Software Services.

\section{Appendix 1}

Table A1: Descriptive statistics of variables used.

\begin{tabular}{|c|c|c|c|c|c|}
\hline \multicolumn{6}{|c|}{ Water Entitlement Model } \\
\hline & Mean & $\begin{array}{l}\text { Standard } \\
\text { Deviation }\end{array}$ & Range & Minimum & Maximum \\
\hline Inaeprice & 6.57 & 0.44 & 2.00 & 5.49 & 7.48 \\
\hline Inaaprice & 3.99 & 1.05 & 4.51 & 2.06 & 6.56 \\
\hline Inalloc & 4.52 & 0.61 & 3.35 & 1.95 & 5.30 \\
\hline drought & 0.25 & 0.44 & 1.00 & 0.00 & 1.00 \\
\hline ndkyab & 118.76 & 86.28 & 339.60 & -57.40 & 282.20 \\
\hline lnfarmgdp & 8.52 & 0.20 & 0.85 & 7.99 & 8.84 \\
\hline month & 0.35 & 0.48 & 1.00 & 0.00 & 1.00 \\
\hline lnpricerw & 1.55 & 0.19 & 0.80 & 1.13 & 1.93 \\
\hline yeartrend & 8.11 & 3.94 & 13.00 & 1.00 & 14.00 \\
\hline policy & 0.08 & 0.27 & 1.00 & 0.00 & 1.00 \\
\hline \multicolumn{6}{|c|}{ Water Allocation Model } \\
\hline Inaaprice & 4.00 & 1.03 & 4.16 & 2.06 & 6.21 \\
\hline Inalloc & 4.48 & 0.65 & 3.69 & 1.61 & 5.30 \\
\hline drought & 0.24 & 0.43 & 1.00 & 0.00 & 1.00 \\
\hline ndkyab & 113.02 & 86.54 & 346.10 & -57.40 & 288.70 \\
\hline lnpricefb & 5.18 & 0.21 & 0.95 & 4.70 & 5.64 \\
\hline lnpricerw & 1.54 & 0.18 & 0.79 & 1.13 & 1.93 \\
\hline lnfarmgdp & 8.52 & 0.19 & 0.85 & 7.99 & 8.84 \\
\hline month & 0.32 & 0.47 & 1.00 & 0.00 & 1.00 \\
\hline yeartrend & 8.21 & 3.80 & 13.00 & 1.00 & 14.00 \\
\hline policy & 0.07 & 0.26 & 1.00 & 0.00 & 1.00 \\
\hline
\end{tabular}




\section{References}

[1] Bjornlund, H. \& Rossini, P. Are the fundamentals emerging for more sophisticated water market instruments? Proceedings from the 14th Annual Conference of the Pacific Rim Real Estate Society, Kuala Lumpur, Malaysia, January. Available at www.prres.net, 2008.

[2] Wheeler, S., Bjornlund H., Shanahan M. \& Zuo, A., Price Elasticity of Allocation Water Demand in the Goulburn-Murray Irrigation District, Australian Journal of Agricultural and Resource Economics, 52, pp. 3755, 2008.

[3] Bjornlund, H. Increased participation in Australian Water Markets. In G. Lorenzini, and C. Brebbia Eds. Sustainable Irrigation Management, Technologies and Policies, Southampton: WIT Press, pp. 289-302, 2006.

[4] Scheierling S., Loomis, J. \& Young R., Irrigation water demand: A metaanalysis of price elasticities, Water Resources Research, 42, W01411, 2006.

[5] Wheeler, S., Bjornlund H., Shanahan M. \& Zuo, A., Price Elasticity and the Demand for Water Entitlements in the Goulburn-Murray Irrigation District of Australia, paper accepted for presentation at Water Down Under conference, 2008, Adelaide.

[6] Colby, B., Crandall, K. \& Bush D., Water right transactions - market values and price dispersion, Water Resources Research, 29, pp.15651572, 1993.

[7] Person, P. \& Michelsen A., Determinants and Trends in Water Right Prices: An Econometric Analysis, Wyoming Water Resources Center, Laramie, Wyoming, 1994.

[8] Bjornlund, H. \& Rossini, P., Fundamentals determining prices in the market for water entitlements - an Australian Case Study, International Journal of Water Resources Development, 23, pp. 537-553, 2007.

[9] Bjornlund, H. (2002): Signs of Maturity in Australian Water Markets New Zealand Property Journal, July, 31-46

[10] Bjornlund, H. \& Rossini, P. Fundamentals determining prices and activities in the market for water allocations, International Journal of Water Resource Development, 21, pp. 355-69, 2005.

[11] Goodwin, B., Schnepf R. \& Dohlman, E., Modelling Soybean Prices in a Changing Policy Environment, Applied Economics, 37, pp. 253-263, 2005.

[12] Brennan, D. Water policy reform in Australia: lessons from the Victorian seasonal water market, The Australian Journal of Agricultural and Resource Economics, 50, pp. 403-423, 2006. 